\title{
Pollen morphology of species of Graphistylis B. Nord. [Asteraceae] of Brazil
}

\author{
Mariana Albuquerque de Souza', Claudia Barbieri Ferreira Mendonça', \\ Roberto Lourenço Esteves ${ }^{2}$ and Vania Gonçalves-Esteves ${ }^{1 *}$
}

Received: November 17, 2015

Accepted: December 17, 2015

\begin{abstract}
This paper presents the results of a palynological study of the species of Graphistylis that were segregated from Senecio (s.l.) (Senecio sect. Dichroa) and that are all endemic of Brazil. These species are found in mountainous regions of the states of Espirito Santo, Minas Gerais, Paraná, Rio de Janeiro, São Paulo and Santa Catarina. The pollen grains of eight species were acetolyzed and analyzed and photographed using light microscopy. Unacetolyzed pollen grains were analyzed and photomicrographed using scanning electron microscopy. The current study undertook a palynologically analysis of Graphistylis in order to obtain information useful for making a better ranking of these genus. The results show medium-sized pollen grains that were oblate spheroidal or prolate spheroidal and subtriangular amb and tricolporate. The pollen grains possessed lalongate endoapertures with a median constriction and the presence of costa in only two species. The exine is echinate with a varying number of spines in the apocolpium region around the central spine in polar view. The spines are short with basal perforations at varying distances. Although the morphology of the pollen of species of Graphistylis is very similar, multivariate analysis highlights the importance of quantitative traits in distinguishing species.
\end{abstract}

Keywords: cluster analysis, ordination analysis, palynology, pollen grains, Senecioneae

\section{Introduction}

The genus Graphistylis is endemic to Brazil where it is found in the mountainous regions of the states of Espírito Santo, Minas Gerais, Rio de Janeiro, São Paulo, Paraná and Santa Catarina (Nordenstam 1978; Jeffrey 1992). It is in the tribe Senecioneae (Cassini 1818), which is considered the largest tribe of Asteraceae with approximately 3500 species distributed among 150 genera (Nordenstam 2007).

Graphitylis was created by Nordenstam (1978) for all six of the species of Senecio sect. Dichroa. Zardini (1992) described a new species of Senecio sect. Dichroa, Senecio serranus, endemic to Paraná. Hind (1993) placed Cacalia dichroa in Graphistylis (G. dichroa) and, a year later, Nordenstam (1994) proposed the combination Graphistylis serrana for Senecio serranus. Teles \& Nordenstam (2008) described a new species endemic to Minas Gerais, Graphistylis riopretensis, resulting in a total of nine species in the genus.

The forms of the style-arm apices are useful for distinguishing species within the genera of Senecioneae. In Senecio, the style-arm apices may be truncated, convex, circular or rhombic, with papillae varying in length, form, and distribution (Jeffrey et al. 1975).

It was mainly based on the characteristics of the style arms that Graphistylis was segregated from Senecio s.l. In Graphistylis, species are easily recognized by having style arms that have a conspicuous tuft of trichomes emerging from the apex of the central arm, surrounded by a crown of shorter trichomes.

The morphology and ultrastructure of pollen grains have been useful in the systematics of Asteraceae, and although part of the family has been well studied palyno-

\footnotetext{
${ }^{1}$ Departamento de Botânica, Museu Nacional, Universidade Federal do Rio de Janeiro, Quinta da Boa Vista, 20940-040, Rio de Janeiro, RJ, Brazil

${ }^{2}$ Departamento de Biologia Vegetal Roberto Alcântara Gomes, Universidade do Estado do Rio de Janeiro, 20940-040, Rio de Janeiro, RJ, Brazil

* Corresponding author: esteves.vr@gmail.com
} 
logically, there have been few such studies of Brazilian species (Mendonça \& Gonçalves-Esteves 2000).

Several authors have studied the palynology of the tribe Senecioneae and the genus Senecio, such as Skvarla \& Turner (1966), Moore \& Webb (1978), Vincent \& Norris (1989), Bolick (1991), Otieno \& Tadesse (1992), Hodolová \& Mártonfi (1995), Melhem et al. (2003), Cancelli et al. (2006, 2007), Medeanic et al. (2008) and Cancelli (2008), although no study has investigated the pollen grains of the species of Graphistylis.

Bibliographical surveys found that the only taxonomic studies addressing species of Graphistylis (previously subordinate to Senecio sect. Dichroa) were those conducted by Cabrera (1957), Nordenstam (1978) and Teles (2008).

Therefore, the present study aims to fill this gap in knowledge by palynologically analyzing the species of Graphistylis and, consequently, provide information that will aid in better classifying this genus.

\section{Materials and methods}

Pollen grains of all species of Graphistylis B. Nord. were analyzed. Pollen material was obtained from fertile anthers of flowers in anthesis and/or from buds in pre-anthesis, derived from samples deposited in herbaria in southeastern and southern Brazil: MBM, R, RB and RFA. Acronyms are in accordance with Thiers (continuously updated).

\section{Examined material}

Graphistylis argyrotricha (Dusén) B. Nord.: Brazil. Rio de Janeiro: Itatiaia, Itatiaia National Park, 19.IV.1957, Luiz Emygidio 1477*(R); Itatiaia, Itatiaia National Park, X.1964, Segadas-Vianna et al. s/n. R158027; Itatiaia, Itatiaia National Park, 16.II.1958, Fuad Atala s/n. R158030; Itatiaia, Itatiaia National Park, 08.III.1980, Soares Nunes 236 (R); Passa Quatro, Itaguaí, 29.VI.2006, Brade 19022 (RB).

Graphistylis cuneifolia (Gardner) B. Nord.: Brazil. Rio de Janeiro: Teresópolis, Serra dos Órgãos National Park, II/1953, J. Vidals/n R157909*; Rio de Janeiro: Teresópolis, Serra dos Órgãos, Pedra da Baleia, III/1952, J. Vidal 5734 (R); Rio de Janeiro: Serra dos Órgãos, Teresópolis, s/d, J. Vidal $s / n, \mathrm{R} 158136$. Teresópolis, Serra dos Órgãos National Park, 28.II.1931, A.C. Brade 10934(R).

Graphistylis dichroa (Bong.) D.J.N. Hind.: Brazil. Goiás: Niquelândia, 15.IV.1996, R. Marquete 2532* (RB).

Graphistylis itatiaiae (Dusén) B. Nord.: Brazil. Minas Gerais: Serra do Caparão, 13.IX.1941, A.C. Brade 16929* (R). Rio de Janeiro: Itatiaia, Itatiaia National Park, 21.VI.1930, A.C. Brade 10096 (R); Itatiaia, Itatiaia National Park, Brejo da Lapa, 22.X.1998, R.L. Esteves 967 (R); Itatiaia, Itatiaia National Park, Prateleiras, VI.1943, Fernando Vianna s/n (RFA23077). Graphistylis oreophila (Dusén) B. Nord.: Brazil. Minas Gerais: Campos dos Caparaós, bordering Espírito Santo,
21.XII.1957, Adolpho Lutz 1203*(R); Serra de Ibitipoca, I. 1895, H. Magalhães $s / n$ (R156855). Rio de Janeiro: Itatiaia, Itatiaia National Park, 25.V.1961, Edmundo Pereira et al. 5697 (R); Itatiaia, Itatiaia National Park, s/d, A.J. Sampaio 4730 (R).

Graphistylis organensis (Casar.) B. Nord.: Brazil. Minas Gerais: São João D’el Rei, IV.1921, Bertha Lutz s/n* (R44825). Rio de Janeiro: Teresópolis, Serra dos Órgãos National Park, Pedra do Sino, V.1953, J. Vidal 6691 (R); Teresópolis, Serra dos Órgãos National Park, Campo das Antas, III.1942, Luiz Emygdio et al. s/n R37291; Pedra da Tijuca, Ernani de Almeida Anselmo s/n (R156857).

Graphistylis serrana (Zardini) B. Nord.: Brazil. Minas Gerais: Serra do Ibitipoca, 13.V.1970, P.L. Krieger 8640* (R). Rio de Janeiro: Itatiaia, Itatiaia National Park, 19.IV.1957, Luiz Emygdio 1478 (R). Paraná: Serra do Ibitiraquire, trail to Caratuva peak, 16.V.2004, J.M. Silva et al. 4082 (MBM). São Paulo: Serra da Bocaína, 16.I.2004, O.S. Ribas et al. 5789 (MBM).

Graphistylis toledoi (Cabr.) B. Nord.: Brazil. São Paulo: Morro da Boa Vista, s/d, Segadas-Vianna 2583* (R); Serra da Bocaína, Morro da Boa Vista, 7.V.1951, A.C. Brade 20894 (RB); Serra da Bocaína, Morro da Boa Vista, 25.III.1964, Segadas-Vianna et al. 2533 (R); Serra da Bocaína, Morro da Boa Vista, III.1951, Segadas-Vianna 2573 (R).

For light microscopy, pollen material was processed according to the method of acetolysis established by Erdtman (1952) with the modifications proposed by Melhem et al. (2003).

Slides were deposited in the Palynology Collection of Alvaro Xavier Moreira Palynology Laboratory, in the Botany Department at National Museum of Federal University of Rio de Janeiro.

For scanning electron microscopy (SEM), anthers were macerated and the pollen grains, non-acetolyzed, were pulverized over stubs covered in carbon tape (Melhem et al. 2003). The pollen was metallized with a layer of pure gold for approximately 3 minutes and subsequently analyzed using a JSM-5310 SEM of the Hertha Meyer Ultrastructure Laboratory of the Biophysics Institute at the Federal University of Rio de Janeiro and a JEOL JSM 6390 LV SEM at the Electronic Microscopy Laboratory of Invertebrates of the National Museum, Federal University of Rio de Janeiro.

For descriptions and illustrations a specimen considered as "standard" was selected for each studied species and is indicated by an asterisk $\left(^{*}\right)$ after the name of the collector. In order to document morphometric variation we studied, when possible, up to four specimens for each species as "material for comparison" (Abreu et al. 2014; Mezzonato-Pires et al. 2015; Vignoli-Silva et al. 2015).

The polar and equatorial views of pollen grains from the standard material were measured. Random measurments included twenty-five measurements of polar (PD) and equatorial (ED) diameters in equatorial view, 10 meas- 
urements of equatorial diameter in polar view (EDPV) and 10 measurments of the apocolpium side (AS).

Additionally, for each species 10 measurements of the aperture and endoaperture (length and width) were taken, as well as exine thickness (sexine and nexine), length, and width and the distance between the spines.

The arithmetic mean ( $\bar{x})$, standard deviation (s), the standard deviation of the mean $\left(\mathrm{s}_{\mathrm{x}}\right)$ and the confidence interval of $95 \%$ (CI) were calculated for each sample. The statistical results are shown in tables. The standard deviation and the coefficient of variation of the sample were calculated to confirm the results, but are not included in the tables.

Terminology for size, shape, number of apertures and the pattern of sexine ornamentation follows Punt et al. (2007). Descriptions of the polar area and the aperture size follow the classification established by Faegri \& Iversen (1966) for the polar area index.

Electron micrographs and photomicrographs were transformed into shades of gray and modified for contrast and brightness using Corel Draw X5.

Exploratory data analysis was carried out using the PC-ORD version 5.31 (McCune \& Mefford 2011) program. Pollen features of the analyzed species were organized in a matrix with 17 variables. In the graphs species names were abbreviated with the first three letters and pollen features (variables) were expressed as numbers.

Variables included in the multivariate analysis with their respective numbers in parentheses were: PD (1), ED (2), P/E (3), length (4) and width of colpo (5), length (6) and width of endoaperture (7), EDPV (8), AS (9), IPA (10), exine (11), sexine (12), nexine (13), costa (14), seven spines in the apocolpium (15), six spines in the apocolpium (16), five spines in the apocolpium (17).,Qualitative characters were presented in the matrix as (1) for present or (0) for absent. In order to avoid ambiguities regarding characters and to minimize possible erros, the categorical variables of shape and size of pollen grains and polar area were removed from the matrix since corresponding measured variables were already included (P/E, PD, ED and IPA).

Measured data used in the multivariate analyses (PCA and Cluster Analysis) were standardize by $1 / 2$ power square root transformation.

Principal component analysis (PCA) was conducted to determine whether the pollen features could cluster species. The variance and covariance matrix (var-cov) was obtained from the means of the morphometric data of the palynological analysis, and the coordinates in the biplot graph are based on Euclidian distances and show the first and second principal components. The matrix of characters, the values of the vectors in each axis and the total of accumulative variance are presented in tables.

The cluster analysis (AHC Clustering) was conducted with the aim of classifying the analyzed species into groups based on shared pollen variables (similarity). Two factors were considered in forming the groups from the set of analyzed variables: the percentage of information (variables) necessary to arrive at the groups related to the final number of groups formed. A dendrogram was made using Euclidian distances (Caccavari et al. 2008) and using Ward's linkage method.

\section{Results}

\section{Dispersion and unit size}

Graphistylis pollen grains (Figs. 1, 2) are monads of medium size, ranging from 36.6 to $49.3 \mu \mathrm{m}$ in polar diameter and 37.3 to $49.7 \mu \mathrm{m}$ in equatorial diameter (Tab. 1).

\section{Polarity, shape and polar area}

All the species examined have isopolar pollen grains that are radially symmetrical, oblate spheroidal or prolate spheroidal, and subtriangular in shape. The polar area ranges from very small in G. argyrotricha, G. itatiaiae and G. serrana, to small in the other species (Tab. 2).

The smallest confidence intervals for polar and equatorial diameters in equatorial view were for $G$. toledoi $(\mathrm{PD}=36.0-37.2 \mu \mathrm{m} ; \mathrm{ED}=36.7-37.9 \mu \mathrm{m})$, and the largest for G. cuneifolia $(\mathrm{PD}=48.9-49.7 \mu \mathrm{m} ; \mathrm{ED}=49.1-50.3 \mu \mathrm{m})$.

\section{Pollen grain apertures}

The pollen grains are tricolporate; the ectoaperture is restricted to an ornamented aperture area (Fig. 2L, bracket) of varying dimensions and whose limits are usually poorly define their limits within the ectoaperture. The ectoaperture range from being long to very long, and are narrow with acute ends and lalongate endoaperture (Tab. 3), and possess a median constriction (Figs. 1B, 2F).

The longest aperture area was found in G. dichroa (ca. $28.8 \mu \mathrm{m})$ and the shortest was in G. toledoi (ca. $23.7 \mu \mathrm{m})$. The longest colpus was found in G. organensis (ca. $19.6 \mu \mathrm{m}$ ) and the shortest in G. toledoi (ca. $13.4 \mu \mathrm{m}$ ); the longest endoaperture was found in $G$. serrana $(7.7 \mu \mathrm{m})$, and the shortest in G. argyrotricha $(3.1 \mu \mathrm{m})$; the smallest width was found in G. toledoi (ca. $14.7 \mu \mathrm{m}$ ) and the largest in G. dichroa $(18.2 \mu \mathrm{m})$. When seen in equatorial view, a row with five to seven pairs of spines can be seen bordering the aperture (Figs. 1F, G, 2B, L). Graphistylis oreophila (Fig. 2A, arrow) and G. organensis (Fig. 2D, arrow) were the only two species with costa.

\section{Exine stratification and ornamentation}

The exine is thick, caveate (Fig. 1A, D), and with a sexine of two layers of columellae separated by an infratectum, both of which are difficult to measure (Fig. 1A, D). The widest cavea was found in G. cuneifolia (ca. $2.5 \mu \mathrm{m}$ ), and 


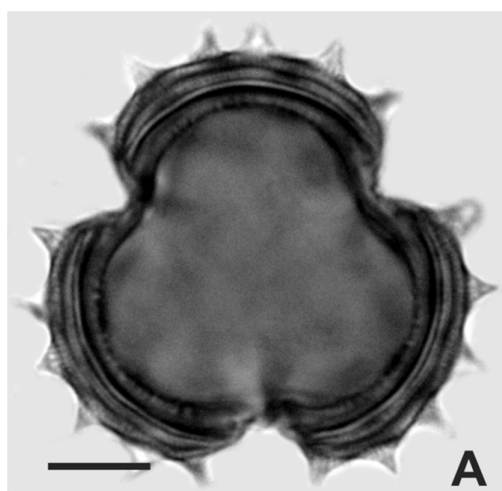

A
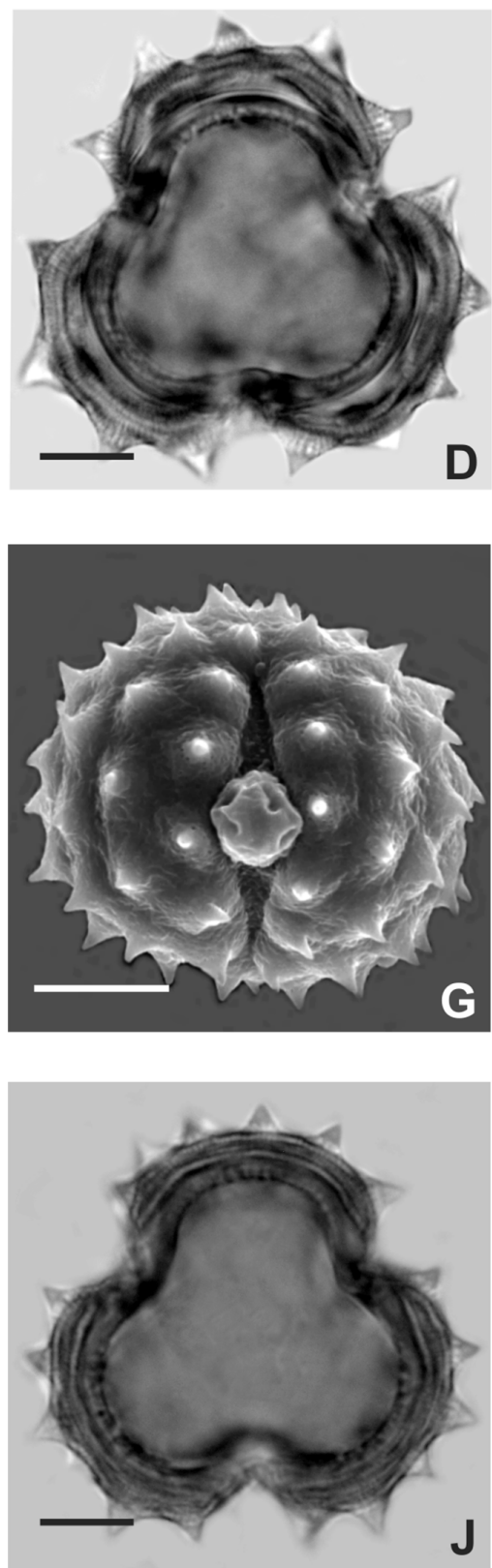
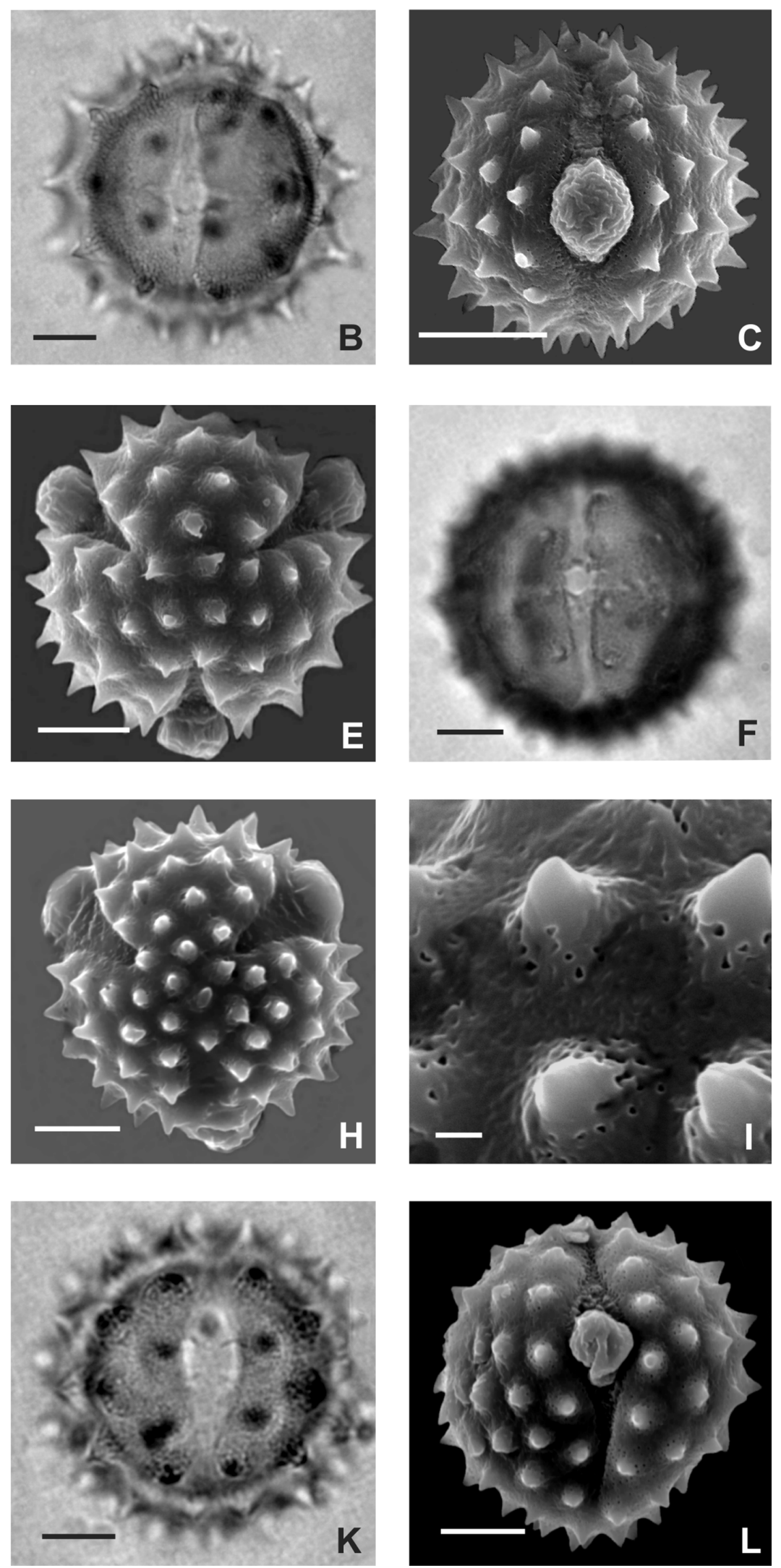

Figure 1. Photomicrographs and eletromicrographs of species of Graphistylis (Asteraceae). G. argyrotricha A. polar view showing the layers of the exine (arrow) (LM); B. equatorial view (LM); C. equatorial view (SEM). G. cuneifolia D. polar view (LM); E. polar view (SEM); F. equatorial view (LM); G. equatorial view (SEM). G. dichroa H. polar view (SEM); I. surface detail (SEM). G. itatiaiae J. polar view (LM); K. equatorial view (LM); I equatorial view (SEM). Scales bar: 1-8, 10-12= $10 \mu \mathrm{m} ; 9=1 \mu \mathrm{m}$. 

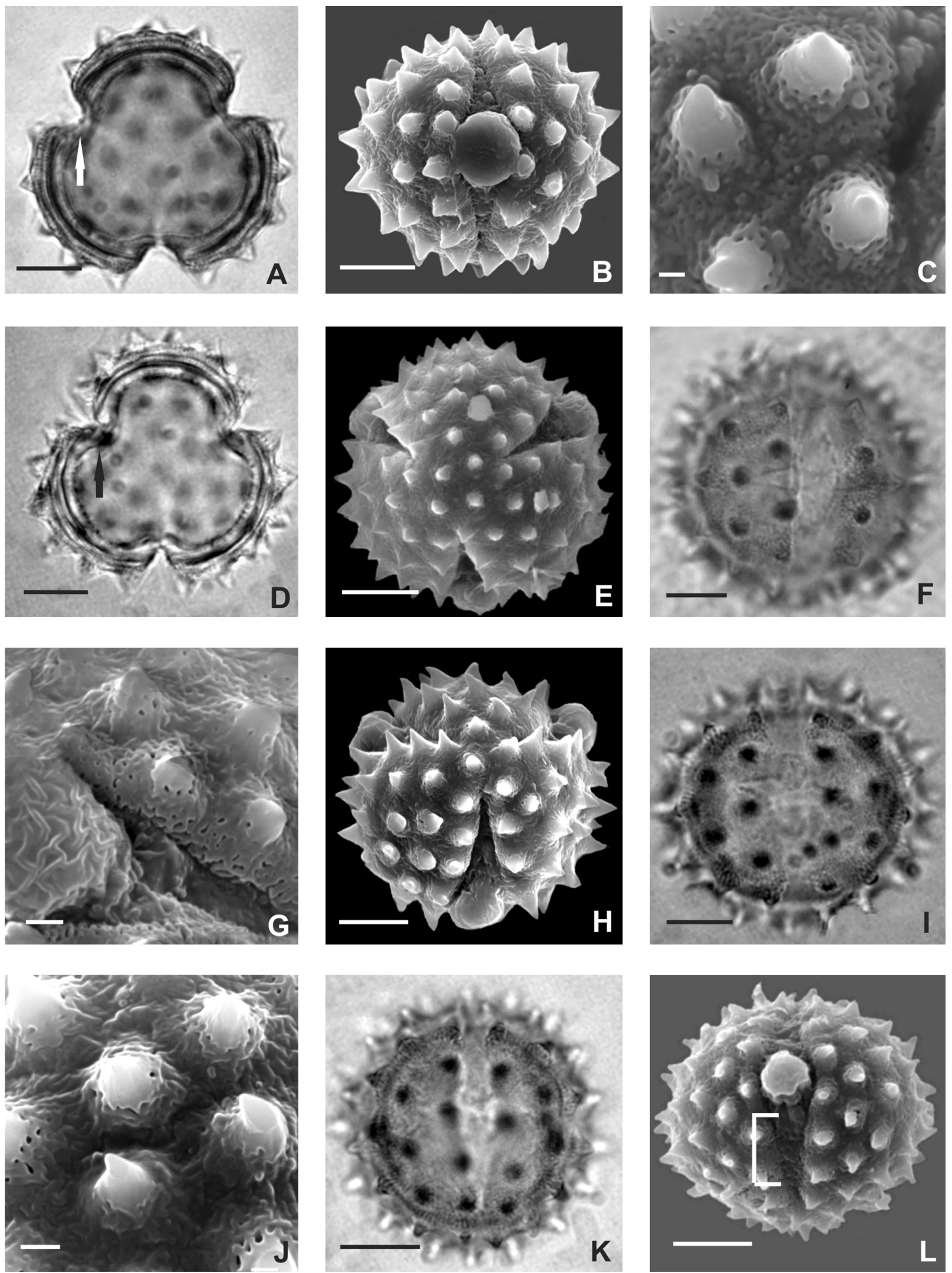

Figure 2. Photomicrographs and eletromicrographs of species of Graphistylis (Asteraceae). G. oreophila A. polar view showing the costa (arrow) (LM); B. equatorial view (SEM); C. surface detail showing spines (SEM). G. organensis D. polar view showing costa (arrow) (LM); E. polar view (SEM); F. equatorial view (LM); G. surface detail. G. serrana H. polar view (SEM); I. equatorial view (LM); J. surface detail. G. toledoi K. equatorial view (LM); L. equatorial view, square bracket (SEM). Scales bar: 1, 2, 4-6, 8, 9=10 $\mu \mathrm{m} ; 3,7,10=1 \mu \mathrm{m}$ 
Table 1. Measurements ( $\mu \mathrm{m})$ of pollen grains in equatorial view of species of Graphistylis (Asteraceae) ( $\mathrm{n}=25)$ : polar diameter (PD); equatorial diameter (ED), arithmetic mean $(\overline{\mathrm{x}})$; standard deviation $\left(\mathrm{s}_{\overline{\mathrm{x}}}\right)$; confidence interval $(\mathrm{CI} 95 \%)$; PD/ED = relationship between the polar and equatorial diameters.

\begin{tabular}{|c|c|c|c|c|c|c|c|}
\hline \multirow[t]{2}{*}{ Species } & \multicolumn{3}{|c|}{ Polar diameter (PD) } & \multicolumn{3}{|c|}{ Equatorial diameter (ED] } & \multirow[t]{2}{*}{ PD/ED } \\
\hline & Range & $\overline{\mathrm{x}} \pm \mathrm{s}_{\bar{\chi}}$ & CI 95\% & Range & $\overline{\mathrm{x}} \pm \mathrm{s}_{\bar{\chi}}$ & CI 95\% & \\
\hline G. argyrotricha & $45.0-48.8$ & $46.3 \pm 0.3$ & $45.7-46.9$ & $42.5-50.0$ & $45.9 \pm 0.3$ & $45.3-46.5$ & 1.01 \\
\hline G. cuneifolia & $47.5-50.0$ & $49.3 \pm 0.2$ & $48.9-49.7$ & $47.5-52.5$ & $49.7 \pm 0.3$ & $49.1-50.3$ & 0.99 \\
\hline G. dichroa & $40.0-47.5$ & $45.3 \pm 0.5$ & $44.3-46.3$ & $38.6-47.5$ & $44.8 \pm 0.5$ & $43.8-45.8$ & 1.01 \\
\hline G. itatiaiae & $45.0-50.0$ & $46.0 \pm 0.3$ & $45.4-46.6$ & $42.5-50.0$ & $46.2 \pm 0.4$ & $45.4-47.0$ & 1.00 \\
\hline G. oreophila & $40.0-47.5$ & $42.6 \pm 0.4$ & $41.8-43.4$ & $40.0-45.0$ & $42.2 \pm 0.3$ & $41.6-42.8$ & 1.01 \\
\hline G. organensis & $45.0-47.5$ & $46.0 \pm 0.3$ & $45.4-46.6$ & $42.5-47.5$ & $45.2 \pm 0.2$ & $44.8-45.6$ & 1.02 \\
\hline G. serrana & $42.5-45.0$ & $43.4 \pm 0.2$ & $43.0-43.8$ & $42.5-47.5$ & $44.8 \pm 0.3$ & $44.2-45.4$ & 0.97 \\
\hline G. toledoi & $35.0-40.0$ & $36.6 \pm 0.3$ & $36.0-37.2$ & $35.0-40.0$ & $37.3 \pm 0.3$ & $36.7-37.9$ & 0.98 \\
\hline
\end{tabular}

Table 2. Measurements ( $\mu \mathrm{m}$ ) of pollen grains in polar view of species of Graphistylis (Asteraceae) (n=10): equatorial diameter (EDPV); apocolpus side (AS) AS - apocolpium side; PAI - polar area index; $(\bar{x})$ range.

\begin{tabular}{|c|c|c|c|c|c|}
\hline \multirow[t]{2}{*}{ Species } & \multicolumn{2}{|c|}{ EDPV } & \multicolumn{2}{|c|}{ AS } & \multirow[t]{2}{*}{ PAI } \\
\hline & Range & $\bar{x}$ & Range & $\bar{x}$ & \\
\hline G. argyrotricha & $42.5-47.5$ & 45.0 & $10.0-12.5$ & 10.8 & 0.24 \\
\hline G. cuneifolia & $45.0-50.0$ & 49.3 & $10.0-15.0$ & 13.3 & 0.26 \\
\hline G. dichroa & $37.5-47.5$ & 44.7 & $10.0-12.5$ & 11.8 & 0.26 \\
\hline G. itatiaiae & $42.5-47.5$ & 45.5 & $10.0-12.5$ & 11.0 & 0.24 \\
\hline G. oreophila & $40.0-45.0$ & 43.4 & $12.5-17.5$ & 13.5 & 0.31 \\
\hline G. organensis & $42.5-47.5$ & 45.3 & $10.0-15.0$ & 12.3 & 0.27 \\
\hline G. serrana & $42.5-45.0$ & 44.4 & $5.0-7.5$ & 7.1 & 0.16 \\
\hline G. toledoi & $37.5-38.0$ & 37.6 & $7.5-10.0$ & 9.8 & 0.26 \\
\hline
\end{tabular}

the narrowest in G. argyrotricha (ca. $0.5 \mu \mathrm{m})$. SEM reveals that the surface between the spines is striate (Figs. 1I, 2C, $\mathrm{G}, \mathrm{J}$ ) with more prominent grooves in G. oreophila (Fig. $2 C)$. The sexine is always much thicker than the nexine.

The spines are short (3.0-4.8 $\mu \mathrm{m})$, wide $(3.4-6.6 \mu \mathrm{m})$, and with perforations at the base and at varying distances; G. argyrotricha, G. cuneifolia, G. oreophila and G. organensis having the greatest distance between spines (Tab. 3).

The spines possess projections formed by the layers of columellae at their base, with the width of the base of the spines being less than the area between spines (Figs. 1D, J, 2A, D). G. cuneifolia had the widest (ca. $6.6 \mu \mathrm{m})$ and furthest apart spines (ca. $12.6 \mu \mathrm{m}$ ). G. argyrotricha, G. serrana and $G$. toledoi had the shortest spines (ca. $3.0 \mu \mathrm{m}$ ), while G. argyrotricha, G. dichroa and G. oreophila had the most narrow spines (ca. $3,4 \mu \mathrm{m})$. The smallest distance between spines was found in G. dichroa (ca. $7.6 \mu \mathrm{m}$ ).

The species of Graphistylis vary in the number of spines, in a polar view, in the apocolpium region and in their arrangement around the central spines: G. argyrotricha, G. dichroa, G. oreophila, G. serrana and G. toledoi have six spines (Fig, 1H); G. cuneifolia has seven spines (Fig. 1E); G. organensis (Fig. 2E) and G. itatiaiae have a single central spine surrounded by five spines.

\section{Hierarchical cluster analysis (HCA)}

The cluster analysis of species of Graphistylis produced a dendrogram with a linkage value of 9.09 for explaining the data. Taking into account the percentage of information (variables) and the final number of groups, three groups were recognized when $50 \%$ of the information was analyzed. The species of Group 1 were G. argyrotricha, G. dichroa, G. oreophila, G. serrana and G. toledoi. Group 2 included only G. cuneifolia, and Group 3 contained G. itatiaiae and G. organensis. When $75 \%$ of the information was analyzed, four groups were produced consisting of the previous three groups, but with $G$. serrana and G. toledoi being removed from Group 1 to form a new group (Fig. 3).

\section{Principal component analysis (PCA)}

The first two axes of the PCA explain $64.64 \%$ of the total variance, with first and second axes explaining $43.46 \%$ and $21.18 \%$ of the variance, respectively. The most significant variables of the first principal component are: polar diameter/PD (1), EDPV (8), equatorial diameter/ED 
Mariana Albuquerque de Souza, Claudia Barbieri Ferreira Mendonça,

Roberto Lourenço Esteves and Vania Gonçalves-Esteves

Table 3. Measurements $(\mu \mathrm{m})$ of the aperture and layers of the exine of pollen grains of species of Graphistylis (Asteraceae) ( $\mathrm{n}=10)$ : Sexine - including spine; DBS - distance between spines.

\begin{tabular}{|c|c|c|c|c|c|c|c|c|c|c|c|c|c|}
\hline \multirow{2}{*}{ Species } & \multicolumn{2}{|c|}{ Ectocolpus } & \multicolumn{2}{|c|}{ Endoaperture } & \multicolumn{2}{|c|}{ Apertural area } & \multicolumn{3}{|c|}{ Exine Layers } & \multicolumn{3}{|c|}{ Spine } & \multirow{2}{*}{ Cavea } \\
\hline & length & width & length & width & length & width & exine & nexine & sexine & length & width & DBS & \\
\hline G. argyrotricha & 18.4 & 6.1 & 3.1 & 16.9 & 26.8 & 5.2 & 8.6 & 2.0 & 6.1 & 3.0 & 3.4 & 9.8 & 0.5 \\
\hline G. cuneifolia & 17.0 & 6.8 & 5.3 & 17.8 & 26.1 & 5.6 & 12.4 & 2.0 & 7.9 & 4.8 & 6.6 & 12.6 & 2.5 \\
\hline G. dichroa & 16.5 & 5.5 & 5.8 & 18.2 & 28.8 & 7.3 & 8.3 & 1.8 & 5.6 & 3.3 & 3.4 & 7.6 & 0.9 \\
\hline G. itatiaiae & 15.1 & 5.0 & 5.1 & 16.2 & 25.4 & 6.5 & 8.1 & 2.0 & 5.3 & 3.1 & 4.0 & 8.0 & 0.8 \\
\hline G. oreophila & 15.0 & 4.8 & 5.4 & 16.4 & 24.7 & 4.3 & 8.2 & 2.0 & 5.2 & 3.2 & 3.4 & 9.6 & 1.0 \\
\hline G. organensis & 19.6 & 6.4 & 4.6 & 16.3 & 25.4 & 6.3 & 9.1 & 2.3 & 5.8 & 4.0 & 4.0 & 10.0 & 1.0 \\
\hline G. serrana & 14.7 & 4.5 & 7.7 & 17.2 & 24.8 & 6.8 & 9.1 & 2.0 & 6.1 & 3.0 & 3.6 & 8.4 & 1.0 \\
\hline G. toledoi & 13.4 & 4.6 & 6.5 & 14.7 & 23.7 & 6.5 & 8.3 & 2.0 & 5.7 & 3.0 & 3.5 & 8.4 & 1.0 \\
\hline
\end{tabular}

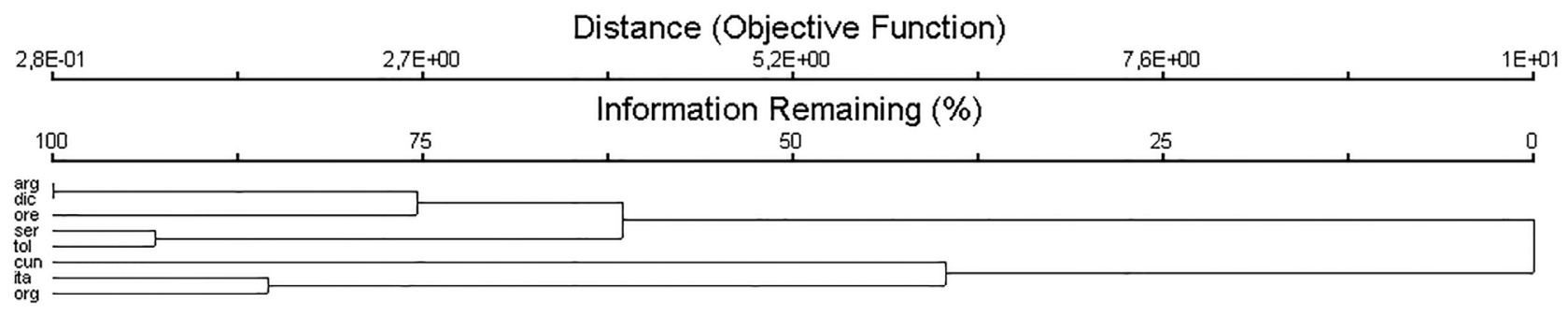

Figure 3. Cluster analysis performed with the measured variables of pollen from Graphistylis (Asteraceae). Abbreviations: arg = G. argyrotricha, cun = G. cuneifolia, dic $=$ G. dichroa, ita $=$ G. itatiaiae, ore $=$ G. oreophila, org $=$ G. organensis, ser $=$ G. serrana, tol $=$ G. toledoi .

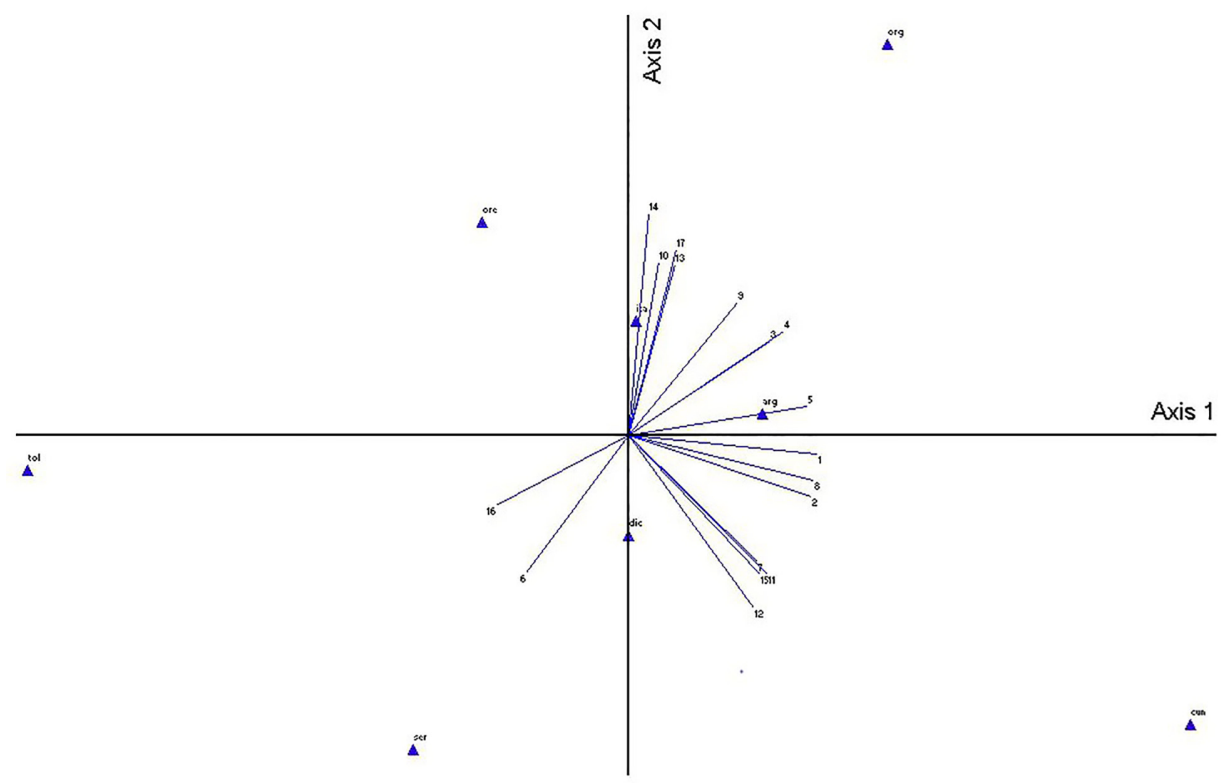

Figure 4. Principal component analysis performed with the mesured variables of pollen from species of Graphistylis (Asteraceae): Abbreviations: arg = G. argyrotricha, cun $=$ G. cuneifolia, dic $=G$. dichroa, ita $=G$. itatiaiae, ore $=$ G. oreophila, org $=$ G. organensis, ser $=G$. serrana, tol $=G$. toledoi. 
(2), and colpus width (7). The most significant variables of the second axis are: presence of costa (14), number of spines on the apocolpium $(15,16,17)$, index of polar area (10) and nexine thickness (13).

The species of Graphistylis are quite dispersed between the positive and negative poles of the first two axes. G. organensis, G. cuneifolia, G. oreophila, G. serrana and G. toledoi are polarized with G. oreophila and $G$. organensis isolated from the other species towards the positive pole of the second axis due to possessing costa; G. organensis separates from G. oreophila because it has one of the longest colpi (4) and P/E (3), and from $G$. cuneifolia at the negative pole of the scond axis because it has the greatest values for PD (1) and ED (2), as well as the thickest exine (11). Variables 6 and 16, corresponding to aperture length and number of spines on the apocolpium, were most significant in grouping G. serrana and G. toledoi, with the latter distancing itself due to smaller values of PD (1) and ED (2).

Although morphologically the pollen grains of species of Graphistylis are very similar, the analyses conducted here highlight the importance of quantitative characters in distinguishing species.

\section{Discussion}

Pollen grain morphology is quite homogeneous among the species of Graphistylis (medium, isopolar, tricolporate, lalongate endoaperture with mean constriction, presence of cavea and echinate sexine). However, they do differ in shape (oblate spheroidal or prolate spheroidal), polar area (small or very small), presence of costa (only in G. oreophila and G. organensis), and size of aperture area. Graphistylis toledoi differed from all other species by having the smallest pollen grains.

Using transmission electron microscopy, Skvarla \& Turner (1966), analyzed the pollen grains of Blennosperma and Crocidium, subordinate genera to the tribes Helenieae and Senecioneae (Asteroideae), respectively. They reached the conclusion that the ultrastructure of the pollen grain wall is a diagnostic characteristic since these genera are closely related. The three large groups of pollen types created by Skvarla \& Larson (1965), and confirmed in Skvarla \& Turner (1966), are: helianthoid, anthemoid and senecioid, the last being characteristic of Senecioneae and Ambrosiineae. Senecioid type of pollen is described as lacking an internal foramen but having a thick basal layer and an interrupted nexine. The pollen grains of Graphistylis are of the senecioid type.

Moore \& Webb (1978) succinctly analyzed Senecio pollen grains and regarded them as not possessing a visible columella below the structure of the echinate tectum. The species of Graphistylis of the present study, formerly regarded as subordinate to Senecio, differ from what was reported by Moore \& Webb (1978) for Senecio, specifically their observation of bacula crossing the tectum in LOanalysis and in optical sectioning.

Using scanning electron microscopy, Vincent \& Norris (1989) analyzed 95 species of Senecio that occur predominantly in South Africa, plus 11 species of genera of the subtribe Senecionineae. These authors described the pollen grains as having a high density of spines that they classified with respect to length/height (very large to moderately large). The authors concluded by affirming that the genus Senecio is closely related to the subtribe Senecionineae, in agreement with the studies of Jeffrey et al. (1978). The results presented herein show that the spines of Graphistylis range from $3 \mu \mathrm{m}$ to $4.8 \mu \mathrm{m}$, while those of Senecio, according to Vincent \& Norris (1989), only reach up to $3 \mu \mathrm{m}$ in length. Therefore, Graphistylis spines would be in the range of "very large" and of high density in the opinion Vincent \& Norris (1989); however, the present study considered these spines as short, thereby differing from these authors.

Bolick (1991) analyzed the size of the pollen grains and exine thickness in species belonging to 14 tribes of the subfamily Asteroideae, and concluded that pollen grains are small and have a proportionately thinner exine. These characteristics were correlated with the type of exine ultrastructure, which may be caveate (helianthoid and senecioid types) or non-caveate (anthemoid and arctoid types). According to the present study, the pollen grains of Graphistylis can be considered senecioid due to the presence of cavea.

In a study of pollen morphology of the family Asteraceae in Rio Grande do Sul, Cancelli et al. (2007) analyzed Senecio cisplatinus Cabrera, S. conyzaefolius Baker, and S. platensis Arechav and found their pollen grains to be medium, suboblate and prolate spheroidal in shape, tricolporate, with lalongate endoaperture, long colpia bordered by four to five pairs of spines, and caveate exine with large columellae at the base of the spines. In the polar view, there were 12-15 large, conic, columellate spines with large bases and tapering apices. The results reported herein for the species of Graphistylis are similar, differing only in shape, and in the number of pairs of spines in the aperture and the apocolpium. The differences in the findings of these two studies underscore the diversity of pollen grains among the species of these two genera.

\section{Conclusion}

According to the literature, the pollen grains of Senecio and Graphistylis are similar, differing mainly in the number of spines and in the appearance of the cavea, which is more apparent in Graphistylis. The pollen grains of the species of Graphistylis are quite homogenous, which was confirmed by the multivariate analysis presented herein. 


\section{Acknowledgments}

We are grateful to Elivaldo Vieira (Museu Nacional, Department Invertebrats-UFRJ), the Cellular Ultrastructure Laboratory of the Biophysics Institute at the Federal University of Rio de Janeiro (UFRJ), and Noêmia R. Gonçalves for technical support with the SEM. The authors would like to thank the financial support by the Research Support Foundation of Rio de Janeiro State (FAPERJ) for lab supplies, and the National Council for Scientific and Technological Development (CNPq) for the research scholarship awarded to the last author.

\section{References}

Abreu VHR, Mendonça CBF, Goncalves-Esteves V. 2014. Pollen morphology of selected species of the subfamily Bombacoideae (Malvaceae sensu lato). Acta Botanica Brasilica 28: 352-360.

Bolick M. 1991. Pollen diameter, exine thickness, and ultrastructure type in the tribes of the Compositae. Compositae Newsletter 19: 17-19.

Cabrera AL. 1957. El genero Senecio (Compositae) en Brasil, Paraguay y Uruguay. Arquivos do Jardim Botânico do Rio de Janeiro 15: 163-264.

Caccavari MA, Naab OA, Tamame MA. 2008. Palynological and physicochemical characteristics of three unifloral honey types from central Argentina. Spanish Journal of Agricultural Research 6: 566-576.

Cancelli RR. 2008. Palinologia de Asteraceae: morfologia polínica e suas implicações nos registros do quaternário do Rio Grande do Sul. MSc Thesis, Universidade Federal do Rio Grande do Sul, Brazil.

Cancelli RR, Evaldt, ACP, Bauermann SG. 2007. Contribuição à morfologia polínica da família Asteraceae Martinov. no Rio Grande do Sul- Parte I. Pesquisas, Série Botânica 58: 347-374.

Cassini H. 1818. Apercu des Genres nouveaux formes par M. Henri Cassini dans La famille des Synanterees. Bulletin de lá Societé Philomatique de Paris 6: 74-75.

Erdtman G. 1952. Pollen morphology and plant taxonomy-Angiosperms. Stockholm, Almqvist \& Wiksell.

Faegri G, Iversen J. 1966. Textbook of modern pollen analysis, 2nd. edn. Copenhagen, Scandinavian University Books.

Hind DJN. 1993. A checklist of the Brazilian Senecioneae (Compositae). Kew Bullettin 48: 279-295.

Hodolová I, Mártonfi, P. 1995. Pollen morphology in the Senecio nemorensis group (Compositae) from the Carpatians. Compositae Newsletter 26: 61-60.

Jeffrey C. 1992. Notes on Compositae, VI: the tribe Senecioneae (Compositae) in the Mascarene Islands with an annotated world check-list of the genera of the tribe. Kew Bullettin 47:49-109.

Jeffrey C, Halliday M, Wilmot-Dear MB, Jones SW. 1975. Generic and sectional limits in Senecio (Compositae): Progress Report. Kew Bullettin 32: 47-67.
McCune B, Mefford MJ. 2011. PC-ORD. Multivariate Analysis of Ecological Data. Version 6. Gleneden Beach, MjM Software.

Medeanic S, Cordazzo CV, Lima LG. 2008. Diversidade polínica de plantas em dunas no extremo sul do Brazil. Gravel 6: 67-80.

Melhem TS, Cruz-Barros MAV, Corrêa MAS, Makino-Watanabe H, Silvestre-Capelato MSF, Gonçalves-Esteves V. 2003 Variabilidade polínica em plantas de Campos de Jordão (São Paulo, Brasil). Boletim do Instituto de Botânica 16: 9-104.

Mendonça, CBF \& Gonçalves-Esteves, V. 2000a. Palinologia de espécies da Tribo Eupatorieae (Compositae Giseke) ocorrentes na Restinga de Carapebus, Rio de Janeiro. Revista Brasileira de Botânica, 23:195-205

Mendonça CBF, Gonçalves-Esteves V. 2000. Morfologia polínica de algumas espécies da tribo Vernonieae (Compositae Giseke) da Restinga de Carapebus, Rio de Janeiro. Hoehnea 27: 131-142.

Mezzonato-Pires AC, Mendonça CBF, Gonçalves-Esteves V. 2015. Pollen morphology of selected species of Passiflora L. (Passifloraceae) from the Atlantic Forest. Acta Botanica Brasilica 29: 391-399.

Moore PD, Webb JA. 1978. An Illustrated Guide to Pollen Analysis. Hodder and Stoughton, London, 133p.

Nordenstam B. 1978. Taxonomic studies in the tribe Senecioneae (Compositae). Opera Botanica 44: 1-84.

Nordenstam B. 1994. New transfers to Graphistylis B.Nord. (Senecioneae). Compositae Newsletter 24: 50-51.

Nordenstam B. 2007. The tribe Senecioneae Cass. 1819. In: Kadereit JW, Jeffrey C. (ed.). The families and genera of vascular plants. Vol. 8. Flowering plants, Eudicots, Asterales. Berlin, Springer. p. 208-241.

Otieno DF, Tadesse M. 1992. Pollen morphological studies in Senecio (Compositae- Senecioneae) from Ethiopia. Compositae Newsletter 20/21: 22-27

Punt W, Blackmore S, Nilsson S, Le Thomas A. 2007. Glossary of pollen and spore terminology. Review of Paleobotany and Palynology 143: 1-81.

Skvarla JJ, Larson DA. 1965. An electron microscopic study of pollen morphology in the Compositae with special reference to the Ambrosiinae. Grana 6: 210- 69

Skvarla JJ, Turner BL 1966. Systematic implications from electron microscopic studies of Compositae pollen - a review. Annals of Missouri Botanical Garden's, Missouri, 53: 220-256.

Teles AM. 2008. Contribuição ao estudo taxonômico da tribo Astereae no Brasil e Senecioneae (Asteraceae) no estado de Minas Gerais. PhD Thesis, Universidade Federal de Minas Gerais, Brazil.

Teles AM, Nordenstam B. 2008. A new species of Graphistylis (Asteraceae: Senecioneae) from Minas Gerais, Brazil. Compositae Newsletter 46: 76-82.

Thiers B [continuously updated] Index Herbariorum: a global directory of public herbaria and associated staff. New York Botanical Garden's Virtual Herbarium. http://sweetgum.nybg.org/ih 15 Nov. 2014.

Vignoli-Silva M, Batista-Franklim CPR, Correa DSM, Mentz LA, Mendonça CBF, Gonçalves-Esteves V. 2015. Pollen diversity in Cestrum L. (Solanaceae) from extra- Amazonian Brazil. Palynology 39: 76-90.

Vincent PLD, Norris FMG. 1989. An SEM study of the external pollen morphology in Senecio and some related genera in the subtribe Senecioninae (Asteraceae: Senecioneae). South African Journal of Botany 55: 304-309.

Zardini EMA. 1992. A new species of Senecio section Dichroa (Asteraceae - Senecioneae) from Brazil. Novon 2: 282-284. 